\title{
The Effect of Fermentation on the Physicochemical Characteristics of Dry-Salted Vegetables
}

\author{
Serap Vatansever ${ }^{1}$, Anuradha Vegi ${ }^{1}$, Julie Garden-Robinson ${ }^{2} \&$ Clifford A. Hall III ${ }^{1}$ \\ ${ }^{1}$ Department of Plant Sciences, North Dakota State University, North Dakota, USA \\ ${ }^{2}$ Department of Health, Nutrition and Exercise Sciences, North Dakota State University, North Dakota, USA \\ Correspondence: Clifford A. Hall III, Department of Plant Sciences, North Dakota State University, Dept. 7670, \\ PO Box 6050, Fargo, North Dakota, 58108-6050, USA. Tel: 1-701-231-6359. E-mail: Clifford.Hall@ ndsu.edu
}

\author{
Received: May 26, 2017 Accepted: July 7, $2017 \quad$ Online Published: August 9, 2017 \\ doi:10.5539/jfr.v6n5p32 URL: https://doi.org/10.5539/jfr.v6n5p32
}

\begin{abstract}
The local food movement has prompted interest in fermented vegetables, especially novel combinations of vegetables. The physicochemical characteristics of dry-salted (2\% Sodium Chloride $[\mathrm{NaCl}])$ fermented carrots, daikon radish, red cabbage, carrot + daikon radish (mix I), and red cabbage + daikon radish (mix II) were examined during a 14-day fermentation at room temperature. The fermentation process was monitored through the measurement of $\mathrm{pH}$, titratable acidity, and Brix value. Further, effects of fermentation on shredded vegetables were determined by measuring color, water activity, and texture (hardness). During the fermentation process, $\mathrm{pH}$ of fermented carrot, daikon radish, red cabbage, and mix I and mix II decreased significantly $(p<0.05)$ to $3.99 \pm 0.04,4.17 \pm 0.05,3.76 \pm 0.11,3.74 \pm 0.18$, and $3.70 \pm 0.05$, respectively, at the end of fermentation (10 days for carrot and 14 days for other vegetables). Titratable acidity (\% as lactic acid) in fermented carrot, daikon radish, red cabbage, and mix I and mix II increased throughout fermentation, and final fermentation day acidity values were $1.39 \pm 0.12,0.78 \pm 0.02,1.54 \pm 0.09,1.2 \pm 0.06$, and $1.50 \pm 0.07 \%$, respectively. In general, fermentation did not impact significantly color, water activity, hardness values of fermented vegetables. The use of the dry-salting method has applications in other vegetables besides cabbage. The study results support the use of this method for other vegetables and also might be useful to provide knowledge helpful in the local food movement.
\end{abstract}

Keywords: lactic acid fermentation, fermented vegetable, dry-salting method, pickling, carrot, daikon radish, red cabbage, local food movement

\section{Introduction}

Fermentation has been used as a simple, economical, and effective food preservation process since ancient times (Joshi \& Sharma, 2009; Kabak \& Dobson, 2011; Hunaefi, Akumo, \& Smetanska, 2013). Some significant advantages of fermentation include: (1) increasing acidity and $\mathrm{pH}$ reduction with the production of organic acids, such as lactic acid by lactic acid bacteria (LAB) and (2) enhancing nutrition, organoleptic, and shelf life properties of foods through by-product (e.g. lactic acids, acetic acids and other volatiles) formation (Joshi \& Sharma, 2009; Hunaefi et al., 2013), and synthesizing essential amino acids and many vitamins (Kabak \& Dobson, 2011) by either useful bacteria, such as LAB or beneficial yeasts, or both (Food and Agriculture Organization [FAO], 1998). Food that is grown 100 miles or less from the point of purchase is considered as local food by US consumers (Dunne, Chambers, Giombolini, \& Schlegel, 2010). Local, sustainable food system projects are being developed and maintained in many communities and their need is on the rise (Feenstra, 2002). The participants in the local food movement use these local food systems as units of measure to increase food security and improve the socio-economic and environmental sustainability of the region (Dunne et al., 2010). Various fermented foods are consumed in the world, such as fermented dairy, meats, cereal, and vegetable products. Fermented dairy and meat products are more commonly produced and consumed when compared to fermented vegetables, and they have a better commercial market than fermented vegetables (Cetin, 2011). Fermented vegetables however, are processed at home using locally grown vegetables (Cetin, 2011). Hence, fermented vegetables will have better marketability in the local food movement as alternative nutritional sources.

Traditional fermented foods have been consumed since ancient times. Besides foods such as fermented dairy, meat and cereal products, fermented vegetables are part of food culture in homes throughout the world (Swain, Anandharaj, Ray, \& Rani, 2014). However, the renewed interest in fermented foods is mainly based on nutrition, 
health and wellness attributed to fermented foods, in addition to their role in increasing the shelf-life of food products by bio-preservation (Martins et al., 2013; Swain et al., 2014). Consumption of foods with probiotics, including fermented products, is increasing world-wide because of the potential health benefits and nutrient composition (Martins et al., 2013). Many studies have shown that fermentation can improve the nutrional value of the foods. For instance, shalgam, a traditional Turkish fermented beverage produced from a mixture of turnip, black carrot, and bulgur through lactic acid fermentation, has high mineral, vitamin, amino acid and polyphenol contents is considered a nutritional fermented juice (Altay, Karbancioglu-Guler, Daskaya-Dikmen, \& Heperkan, 2013).

Fresh vegetables can be preserved using various fermentation methods: (a) Fermentation with dry salting, where vegetables are subjected 2 to $3 \%$ salt addition (w/w), such as sauerkraut, (b) fermentation in brine, where vegetables are subjected to brine (i.e. high content of salt dissolved in water), such as dill pickles, and (c) non-salting fermentation, such as gundruk, which is a cauliflower and cabbage leaves non-salted fermented product (Swain et al., 2014). Traditional fermented vegetables are produced by natural microflora, e.g. LAB, through physicochemical changes that include conversion of sugars in the plant into primarily lactic acid under anaerobic conditions (Karasu, Simsek, \& Con, 2010).

Fermentable sugars, salt concentration, natural microflora, temperature, and available nutrients are important factors affecting vegetable fermentation; therefore, these factors need to be considered during vegetable fermentation (Joshi, Sharma, \& Thakur, 2008). For example, Leuconostoc strains have been reported as the predominant microorganisms during the initial days of fermentation, but as fermentation continued, Lactobacillus species dominate for the remaining fermentation process (Daeschel, Anderson, \& Fleming, 1987).

Sauerkraut produced from Brassica vegetables is a popular natural fermented vegetable in the world, both traditionally and commercially. Sauerkraut is produced from shredded and salted white cabbage via spontaneous fermentation by various LAB present on white cabbage leaves (Kalac, Spicka, Marti, \& Pelikanova, 2000; Hunaefi et al., 2013). Leuconostoc (Lc.) and Lactobacillus (L.) species, particularly L. plantarum and Lc. mesenteroides, are the predominant microflora of sauerkraut during fermentation (Jagannath, Raju, \& Bawa, 2012; Hunaefi et al., 2013). Heterofermentative Leuconostoc species are found at the beginning of the fermentation while homofermentative Lactobacillus and Pediococcus species are present at the end of the fermentation process (Jagannath et al., 2012).

Kimchi is another traditional fermented vegetable produced from a mixture of ingredients, such as cabbage, garlic, ginger, and hot red pepper. The microorganisms present in kimchi during the fermentation period consist of Lactobacillus, Leuconostoc, and Weissella (W.) species. Leuconostoc species are predominant initially, and they compete with Weissella species later. Therefore, different species play an important role in kimchi fermentation (Cho et al., 2006). Other vegetables, such as carrot (Joshi et al., 2008), radish (Joshi \& Sharma, 2009) and red cabbage (Hunaefi et al., 2013) also have been fermented. Pediococcus, Leuconostoc, and Lactobacillus species were present in radish fermentation (Damodharan, Palaniyandi, Yang, \& Suh, 2015).

In this study, carrot (Daucus carota subsp. sativus), daikon radish/Chinese radish (Raphanus sativus L.), red cabbage (Brassica oleracea C.) and their combinations (carrot + daikon radish [1:1], and red cabbage + daikon radish [1:1]) were used with the addition of $2 \% \mathrm{NaCl}$. These vegetables were chosen for several reasons, including the availability of fermentable sugar, and they can be locally grown.

Carrot is a common root vegetable consumed both raw and cooked. Carrot is high in B-carotene content, which is an antioxidant (Aizawa \& Inakuma, 2007; Arslan \& Ozel, 2012), a precursor of vitamin A (Deming, Boileau, Lee, \& Erdman, 2000) and rich in carbohydrates, vitamins (such as $A, B_{1}, B_{2}, C, E$, thiamin and riboflavin) and minerals (such as calcium, phosphorus, iron, potassium) (Arslan \& Ozel, 2012). Besides being rich in nutrients, carrot has other important benefits, such as sweetening, diuretic and antianemic properties (Joshi et al., 2008). Daikon radish is used in Asian countries as a fermented vegetable in kimchi (Jiang et al., 2012; Damodharan et al., 2015), and also has a fairly high water content that facilitates the formation of brine when combined with other vegetables. Cabbage is the preferred vegetable for lactic acid fermentation due to its high fermentable sugar content. However, red cabbage has been used to a lesser extent in cabbage fermentations (Hunaefi et al., 2013), even though it is a rich source of dietary antioxidants. Therefore, the effects of fermentation on red cabbage for traditional use in home production has not been extensively reported.

Recent literature has limited information about vegetables fermented through the dry-salting method, except for sauerkraut. The aim of this study was to develop fermented food products using locally grown vegetables and provide guidelines to produce them by people interested in local foods. To achieve that, (1) the appropriate number of fermentation days for selected vegetables under home-use conditions were determined and, (2) the 
effect of fermentation on the physical and chemical characteristics of selected vegetables was evaluated.

\section{Materials and Methods}

\subsection{Plant Materials and Other Materials}

Carrot, daikon radish, red cabbage, pickling salt $(\mathrm{NaCl})$ and wide-mouthed mason jars $(8 \mathrm{Oz})$ were purchased from a local market in Fargo, ND. To maintain replications, vegetables from separate purchasing dates were subjected to fermentation at three different times. When the first replicate of fermentation was completed, then the next fermentation was started. In the experiment, special fermentation lids (Sauer System Fermentation Lids, USA) were used to maintain anaerobic conditions during fermentation.

\subsection{Lactic Acid Fermentation}

Selected vegetables were fermented spontaneously using a dry salting method (Joshi \& Sharma, 2009; Hunaefi et al., 2013). The vegetables were washed with distilled water and the outer leaves of red cabbage were removed. Carrots and daikon radish were peeled after washing. Red cabbage was cut into $2 \mathrm{~mm}$ thick strips (Hunaefi et al., 2013), while peeled carrot and daikon radish were shredded (Joshi \& Sharma, 2009). Pickling salt (2\% by weight) was mixed with the mass of vegetable based on the traditional sauerkraut-making method (Viander, Maki, \& Palva, 2003; Thakur \& Kabir, 2015). The grated vegetables (125 g per jar) were packed into sterilized mason jars and pressed until brine was observed on the surface of the packed vegetable. Mixed vegetables, mix 1 (50\% carrot and 50\% daikon radish) and mix 2 (50\% red cabbage and 50\% daikon radish), were combined after shredding of vegetables. Thereafter, this mixture was subjected to the similar process. After packing, lids containing fermentation locks were placed tightly on the jars. Vegetables were fermented naturally at room temperature $\left(\sim 24^{\circ} \mathrm{C}\right)$ for 14 days. Samples were taken on days 0 (no fermentation), 3, 7, 10, and 14 to perform chemical and physical analyses.

\subsection{Chemical and Physical Parameter Analyses}

An Orion pH meter (Model 420 A, USA) standardized with pH 4.1 and 7.0 buffers was used to determine $\mathrm{pH}$ of the brine. Titratable acidity was determined using the Association of Official Analytical Chemists (AOAC) official method 962.12 (2000) and recorded as percent lactic acid. ${ }^{\circ}$ Brix value (for soluble solids) was measured using an Atago hand refractometer (PA-27S, USA). Water activity of fermented vegetables was determined using an AQUA LAB Water Activity Analyzer (CX-2, USA).

\subsection{Texture Analysis}

Hardness $(\mathrm{N})$ of fermented vegetables $(25 \mathrm{~g}$ ) was measured with a Brookfield Texture Analyzer (Model CT3 $10 \mathrm{~K}$, USA). The protocol used in the study was modified from Johanningsmeier, Mcfeeters, Fleming, and Thompson (2007). According to the protocol, the test speed employed was $1.3 \mathrm{~mm} / \mathrm{s}$ for the test distance of 25 $\mathrm{mm}$, and hardness $(\mathrm{N})$ was recorded electronically.

\subsection{Colorimetric Analysis}

Color analysis was performed using a Minolta Chroma Meter (Model CR-310, Japan). The $L$ (lightness), $a$ (red-green), and $b$ (blue-yellow) values were recorded. The color difference between the pre-fermentation and post-fermentation of vegetables was determined using $L, a$ and $b$ values from the color analysis via the formula (1) (Anonymous, 2003).

$$
\text { Color Difference }\left(\Delta \mathrm{E}^{*} \mathrm{ab}\right)=\left[\left(\Delta \mathrm{L}^{*}\right)^{2}+\left(\Delta \mathrm{a}^{*}\right)^{2}+\left(\Delta \mathrm{b}^{*}\right)^{2}\right]^{1 / 2}
$$

\subsection{Statistical Analysis}

A randomized complete block design (RCBD) was used as an experimental design to evaluate the data. Fermentation days $(0,3,7,10$, and 14) were chosen as treatments, and each experiment was repeated for three times with two samples per treatment. Analysis of variance (ANOVA) (SAS Version 9.0, SAS Institute, USA) was used to perform statistical analysis. F-protected LSD was used for the separation of means at $\alpha=0.05$ level of confidence.

\section{Results and Discussion}

\section{$3.1 \mathrm{pH}$}

The $\mathrm{pH}$ value is one of the most important physicochemical characteristics of lactic acid fermentations. On day 0 of fermentation, carrot, radish, red cabbage, mix I, and mix II had pH values of $6.11 \pm 0.05,6.29 \pm 0.06,5.72 \pm 0.11$, $6.19 \pm 0.04$, and $5.94 \pm 0.07$, respectively. After 7 days of fermentation, the $\mathrm{pH}$ levels of all vegetables decreased significantly $(p<0.05)$ and ranged between 3.87 and 4.20 (Figure 1). Viander et al. (2003) similarly reported the $\mathrm{pH}$ values (4.0-4.3) after 6 days of fermentation of white cabbage, which was subjected to two different salt and 
mineral salt concentrations. Likewise, Hunaefi et al. (2013) observed pH values of approximately 4.3 and 3.8 in red cabbage that was fermented using $1.5 \% \mathrm{NaCl}$ of natural or inoculated $\mathrm{LAB}$ fermentation for 7 days, respectively. Fermentation of all vegetables continued up to 14 days. However, one replicate of carrot sample had surface mold at day 14 of fermentation; therefore, the results for the carrot fermentation were evaluated for 10 days of fermentation. A combined effect of high carrot starch content (a good energy source for microbial growth), reduced contact between brine and shredded carrots due to lowered brine level on surface, potential decrease of LAB derived antimicrobials, and an additional exposure to oxygen via lowered brine level may have supported the mold growth in the carrot sample. During the remaining fermentation period, $\mathrm{pH}$ in all samples decreased continuously, but the reduction in $\mathrm{pH}$ for all samples was not significantly different after 7 days. Similar results were reported by Hunaefi et al. (2013) for red cabbage fermentation. The $\mathrm{pH}$ values for carrot, daikon radish, red cabbage, mix I, and mix II were 3.99 $\pm 0.04,4.17 \pm 0.05,3.76 \pm 0.11,3.74 \pm 0.18$, and $3.70 \pm 0.05$, respectively, at the end of fermentation (10 days for carrot and 14 days for other plant materials). The reduction in $\mathrm{pH}$ level during the fermentation period of food is desirable and necessary to facilitate LAB growth, which are responsible for lactic acid fermentation, to prevent unwanted microorganisms, such as pathogenic bacteria, molds and yeasts, and to maintain $\mathrm{pH}$ values $(\mathrm{pH}<4.6)$ to prevent the growth of non-beneficial bacteria and ensure food safety (FAO, 1998).

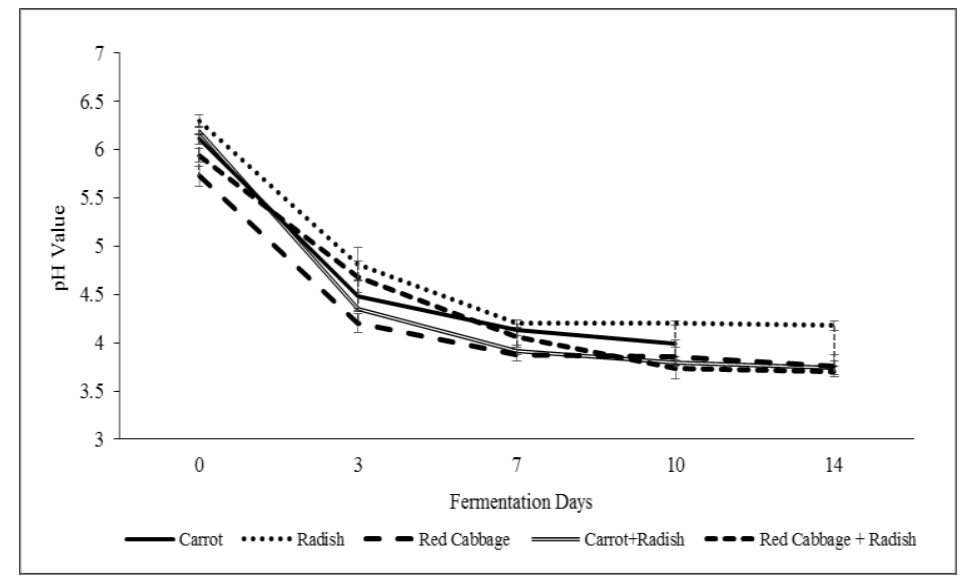

Figure 1. The changes of $\mathrm{pH}$ values in fermented vegetables during fermentation period

Note. The values of means were presented with bars of standard errors.

Fermented daikon radish had higher $\mathrm{pH}$ values than other vegetables. This might be due to less available sugar for the fermentation than other vegetables. The carrot + daikon radish product did not show microbial contamination on the surface in any replicates at day 14 , in contrast to the carrot sample. The addition of daikon radish to carrot increased the brine level of the combined carrot + daikon radish, which allowed the vegetable to remain submerged under brine and prevented surface mold spoilage that was observed in the carrot fermentation.

Mixed samples had lower $\mathrm{pH}$ values than other samples. The brine levels of mixed samples were relatively higher than carrot and red cabbage samples. The higher brine helps in ensuring better anaerobic conditions, which is favorable for LAB growth. In addition, the higher brine level might help to leach more sugar from vegetables; thus, $\mathrm{LAB}$ might be able to utilize more sugar.

The $\mathrm{pH}$ decreased rapidly during the first 3 days of fermentation, which was likely due to higher fermentable sugars present in the vegetables. The reduction of fermentable sugars likely contributed to the lack of significant pH change after day 7. Therefore, after day 7 the fermentation was complete (Joshi \& Sharma, 2009).

\subsection{Total Titratable Acidity (TTA) \%}

At the beginning of fermentation, carrot, daikon radish, red cabbage, mix I, and mix II had relatively low TTA \% (as lactic acid) $0.20 \pm 0.02,0.16 \pm 0.02,0.20 \pm 0.06,0.13 \pm 0.01$, and $0.16 \pm 0.03 \%$, respectively. Afterward, all fermented vegetables had an increased TTA \% during the fermentation period (Figure 2), which depends on the conversion of sugars from shredded vegetables into lactic acid primarily by LAB.

TTA \% is another important criterion to understand the impact of lactic acid fermentation. When TTA\% increases during the fermentation period, which indicates that LAB grew and utilized sugars in plant materials to produce primarily lactic acid and other by-products. Fermented carrot up to 3 days, fermented daikon radish and 
fermented red cabbage up to 7 days, and mix I and mix II up to 10 days of fermentation exhibited significant ( $p$ $<0.05$ ) increased levels of TTA \%. Basically, the lactic acid production continued until all fermentable substrates were utilized. Thereafter, the lactic acid level in the samples was stabilized due to the consumption of all fermentable substrates.

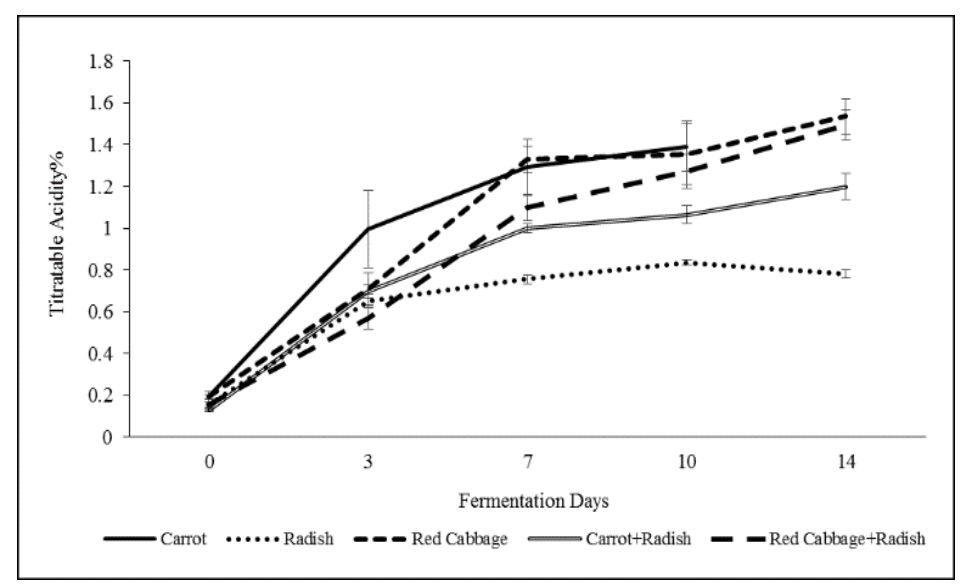

Figure 2. The changes of TTA\% values in fermented vegetables during fermentation period

Note. The values of means were presented with bars of standard errors.

Only fermented daikon radish had a decreased TTA $\%$ at the last day of fermentation, although it was not significant. The TTA\% in the remaining samples tended to increase until the last day of fermentation. In traditional fermentation of vegetables with the dry salting method, weight is used to press vegetables tightly to keep brine on the surface. The use of weight might be useful for maintaining brine above the surface; thus, the brine might help to prevent surface contamination that was observed in the carrot sample. In addition, the microbial growth on the surface of fermented carrot might be inhibited by increasing salt concentration above $2 \%$.

\section{$3.3^{\circ}$ Brix Value}

${ }^{\circ}$ Brix values of fermented carrot, daikon radish, red cabbage, mix I, and mix II at the beginning of fermentation were $8.3 \pm 0.4,6.3 \pm 0.1,5.5 \pm 0.1,8.6 \pm 0.5$, and $5.6 \pm 0.2$, respectively. ${ }^{\circ}$ Brix values of most fermented vegetables increased significantly $(p<0.05)$, up to day 3 and then remained stable throughout the fermentation. Fermented carrot and daikon radish ${ }^{\circ}$ Brix value increased significantly up to day 7 and 10, respectively. Although ${ }^{\circ}$ Brix values of these samples for later fermentation days increased, the changes were not significant (Figure 3).

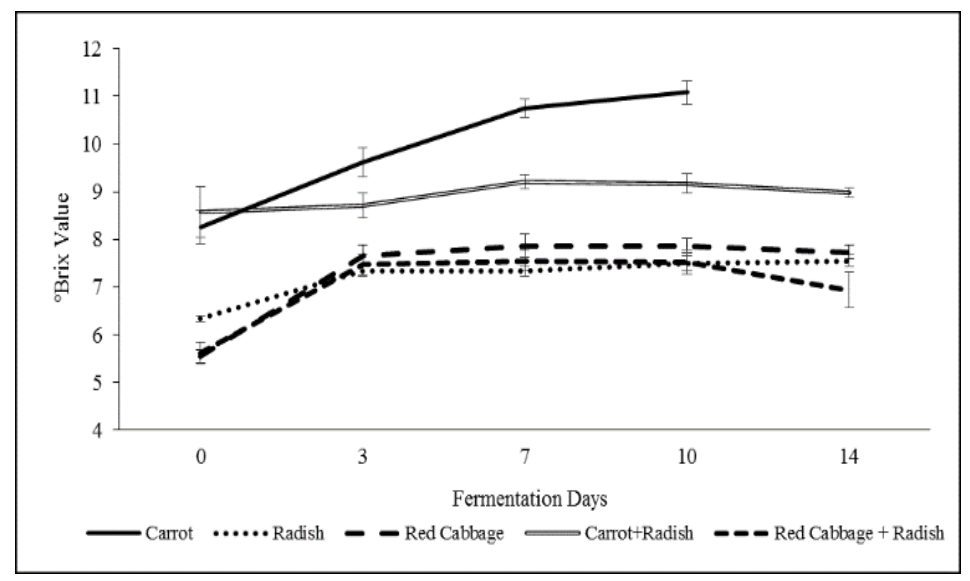

Figure 3. The changes of ${ }^{\circ}$ Brix values in fermented vegetables during fermentation periods

Note. The values of means were presented with bars of standard errors.

The increase in ${ }^{\circ}$ Brix values might be related to the soluble solids. Shredded vegetables with added salt, as a 
result of their increased surface area, facilitate LAB growth and water extraction, compared with whole or larger pieces of vegetables. Thus, ${ }^{\circ}$ Brix values increase rapidly due to the increase in the soluble solids removal in shredded plant materials. The soluble solids are formed by the addition of salt and any soluble materials that leach from the vegetables during fermentation. Small reductions in soluble solids in the brine during the later fermentation days lead to reduced ${ }^{\circ}$ Brix values. Joshi and Sharma (2009) also observed an increase in ${ }^{\circ}$ Brix value of fermented radish up to 8 days, which then decreased with continued fermentation.

\subsection{Water Activity}

The water activities of all plant materials were ideal for LAB growth, from the beginning of fermentation to the last day (Table 1). Except for daikon radish, the results were not significantly $(p<0.05)$ different. Fermented radish water activity was significantly $(p<0.05)$ different up to 10 days. This difference might be associated with the decrease in brine level of fermented daikon radish up to day 10 of the fermentation.

\subsection{Color Value}

The $L, a$, and $b$ values were recorded from day 0 to day 14 (Table 1) except for carrot, which was conducted until day 10. Fermented carrot and fermented mix I color values did not change significantly $(p<0.05)$ during fermentation (Table 1). However, significant differences $(p<0.05)$ in $a$ and $b$ value of fermented daikon radish at day 7 and in $L$ and $b$ values of fermented mix II at day 3 and day 14 were observed.

The color difference (i.e. before and after fermentation) for carrot at day 10, daikon radish, red cabbage, mix I, and mix II at day 14 were calculated as $3.98 \pm 0.51,5.14 \pm 0.67,5.11 \pm 1.49,2.84 \pm 0.55$, and $8.44 \pm 1.15$, respectively (Table 1). The color difference is an indicator of color stability of food products, where lower color difference values suggests better color stability. Among fermented vegetable samples, color change in carrot and mix I were the least during fermentation, where the change in color values of these samples was not significant. However, daikon radish ( $a$ and $b$ values), red cabbage ( $a$ and $b$ values) and mix II ( $L$ and $b$ values) changed during the fermentation process. These changes were significant $(p<0.05)$ while their color difference values were higher than carrot and mix I.

Lactic acid fermentation takes place under anaerobic conditions; thus, oxygen availability is limited and may be the reason for minimal effect on color of fermented carrot and mix I (Lee, 1997). On the other hand, mix II color changed on the surface to a light brown color after 3 days of fermentation. This color change might be due to enzymatic browning promoted by polyphenol oxidase (PPO), which causes the oxidation of phenolic compounds in the food materials and remains active at $\mathrm{pH}$ values of 4.0 to 8.0 (depending on plant sources and temperature) (Mizobutsi et al., 2010).

Hunaefi et al. (2013) reported that red cabbage contained high level of phenolic compounds, and that the fermentation caused a slight increase in phenolic compounds in red cabbage. Others have reported that gallic and chlorogenic acids were present in the red cabbage with other phenolic compounds (Hunaefi et al., 2013) and in radish (Goyeneche, Scala, \& Roura, 2013). Consequently, the combination of red cabbage and daikon radish might have increased phenolic compounds and PPO levels; therefore, this mixture might be a good medium for PPO activity and the formation of enzymatic browning compounds. These color compounds then contributed to a color change more than those associated with carrots.

Compared to mix II, less color change was observed in $a$ and $b$ values of fermented daikon radish and fermented red cabbage. These changes in fermented red cabbage and daikon radish might be caused by several factors. Fermented red cabbage had increased $a$ and $b$ values, specifically after day 7 of fermentation. Red cabbage is relatively high in anthocyanins, which are pigments in red cabbage. A reduction in total anthocyanins in fermented red cabbage was reported due to the low $\mathrm{pH}$, which caused decolorization of the color pigment (Hunaefi et al., 2013). Enzymatic browning, particularly in fermented daikon radish, may be responsible for the significant decrease $(p<0.05)$ in $a$ value and the significant increase $(p<0.05)$ in $b$ values after day 7 of fermentation.

\subsection{Texture Analysis}

Texture in fermented vegetables plays an important role in their general acceptability. Therefore, fermented vegetables were analyzed to determine their texture through measuring the hardness value $(\mathrm{N})$. The hardness value of mix I did change significantly $(p<0.05)$ during fermentation. This change might be related to an increased brine level compared to carrot sample. Daikon radish hardness was significantly different $(p<0.05)$ between the initial day and the last day of fermentation (Table 1). Day 14 daikon radish samples were harder than samples from other fermentation days. The formation of lactic acid and other metabolites might affect the texture of daikon radish as well as the reduction in brine level, which caused the dryness in fermented radish. 
Table 1. The changes in other physicochemical characteristics of fermented vegetables during fermentation days.

\begin{tabular}{|c|c|c|c|c|c|}
\hline \multirow[t]{3}{*}{ Analysis } & \multicolumn{5}{|c|}{ Carrot } \\
\hline & \multicolumn{5}{|c|}{ Time (day) } \\
\hline & 0 & 3 & 7 & 10 & 14 \\
\hline Water Activity & $0.98 \pm 0.00^{\mathrm{a}}$ & $0.98 \pm 0.00^{\mathrm{a}}$ & $0.98 \pm 0.00^{\mathrm{a}}$ & $0.97 \pm 0.00^{\mathrm{a}}$ & $\begin{array}{c}--- \\
-\end{array}$ \\
\hline Hardness (N) & $18.78 \pm 6.06^{\mathrm{a}}$ & $12.27 \pm 1.88^{\mathrm{a}}$ & $12.32 \pm 3.93^{\mathrm{a}}$ & $14.93 \pm 3.82^{\mathrm{a}}$ & ---- \\
\hline Color L & $52.91 \pm 1.08^{\mathrm{a}}$ & $52.20 \pm 1.34^{\mathrm{a}}$ & $51.69 \pm 1.16^{\mathrm{a}}$ & $51.53 \pm 0.92^{\mathrm{a}}$ & ---- \\
\hline Color a & $14.40 \pm 1.59^{\mathrm{a}}$ & $15.27 \pm 2.93^{\mathrm{a}}$ & $14.46 \pm 2.28^{\mathrm{a}}$ & $13.66 \pm 1.84^{\mathrm{a}}$ & --- \\
\hline Color b & $24.43 \pm 2.12^{\mathrm{a}}$ & $22.55 \pm 3.00^{\mathrm{a}}$ & $21.68 \pm 2.46^{\mathrm{a}}$ & $21.03 \pm 2.30^{\mathrm{a}}$ & ---- \\
\hline \multirow[t]{2}{*}{$\Delta \mathrm{E}$} & & $4.13 \pm 0.95^{\mathrm{a}}$ & $4.37 \pm 2.07^{\mathrm{a}}$ & $3.98 \pm 0.51^{\mathrm{a}}$ & ---- \\
\hline & \multicolumn{5}{|c|}{ Radish } \\
\hline Water Activity & $0.98 \pm 0.00^{\mathrm{ab}}$ & $0.98 \pm 0.00^{\mathrm{a}}$ & $0.98 \pm 0.00^{\mathrm{bc}}$ & $0.97 \pm 0.00^{c}$ & $0.97 \pm 0.00^{\mathrm{bc}}$ \\
\hline Hardness (N) & $8.54 \pm 1.33^{b}$ & $7.21 \pm 1.27^{\mathrm{b}}$ & $5.81 \pm 0.90^{\mathrm{b}}$ & $5.28 \pm 0.90^{\mathrm{b}}$ & $18.34 \pm 1.77^{\mathrm{a}}$ \\
\hline Color L & $45.14 \pm 0.43^{\mathrm{a}}$ & $46.91 \pm 0.88^{\mathrm{a}}$ & $46.95 \pm 0.36^{\mathrm{a}}$ & $46.98 \pm 0.38^{\mathrm{a}}$ & $45.65 \pm 0.31^{\mathrm{a}}$ \\
\hline Color a & $-0.52 \pm 0.06^{\mathrm{a}}$ & $-0.9 \pm 0.19^{\mathrm{a}}$ & $-1.73 \pm 0.14^{\mathrm{b}}$ & $-1.82 \pm 0.11^{\mathrm{b}}$ & $-1.81 \pm 0.24^{b}$ \\
\hline Color b & $-2.96 \pm 0.19^{\mathrm{c}}$ & $-0.78 \pm 0.37^{b}$ & $2.32 \pm 0.31^{\mathrm{a}}$ & $2.60 \pm 0.29^{\mathrm{a}}$ & $1.82 \pm 0.48^{\mathrm{a}}$ \\
\hline \multirow[t]{2}{*}{$\Delta \mathrm{E}$} & & $3.21 \pm 0.40^{\mathrm{b}}$ & $5.74 \pm 0.63^{\mathrm{a}}$ & $6.18 \pm 0.31^{\mathrm{a}}$ & $5.14 \pm 0.67^{\mathrm{a}}$ \\
\hline & \multicolumn{5}{|c|}{ Red cabbage } \\
\hline Water Activity & $0.98 \pm 0.00^{\mathrm{a}}$ & $0.98 \pm 0.00^{\mathrm{a}}$ & $0.98 \pm 0.00^{\mathrm{a}}$ & $0.97 \pm 0.00^{\mathrm{a}}$ & $0.98 \pm 0.00^{\mathrm{a}}$ \\
\hline Hardness (N) & $8.31 \pm 1.18^{\mathrm{a}}$ & $11.21 \pm 1.65^{\mathrm{a}}$ & $19.87 \pm 5.24^{\mathrm{a}}$ & $18.74 \pm 6.19^{\mathrm{a}}$ & $18.70 \pm 6.24^{\mathrm{a}}$ \\
\hline Color L & $36.55 \pm 0.17^{\mathrm{a}}$ & $36.21 \pm 0.17^{\mathrm{a}}$ & $36.81 \pm 0.20^{\mathrm{a}}$ & $36.71 \pm 0.24^{\mathrm{a}}$ & $36.81 \pm 0.27^{\mathrm{a}}$ \\
\hline Color a & $4.80 \pm 0.26^{\mathrm{b}}$ & $5.78 \pm 1.00^{\mathrm{ab}}$ & $8.73 \pm 1.53^{\mathrm{a}}$ & $8.00 \pm 1.77^{\mathrm{ab}}$ & $7.44 \pm 1.74^{\mathrm{ab}}$ \\
\hline Color b & $-3.47 \pm 0.63^{b}$ & $-0.52 \pm 0.18^{\mathrm{a}}$ & $0.13 \pm 0.14^{\mathrm{a}}$ & $0.22 \pm 0.09^{\mathrm{a}}$ & $0.26 \pm 0.08^{\mathrm{a}}$ \\
\hline \multirow[t]{2}{*}{$\Delta \mathrm{E}$} & & $3.46 \pm 0.9^{\mathrm{b}}$ & $5.57 \pm 0.86^{\mathrm{a}}$ & $5.63 \pm 1.67^{\mathrm{a}}$ & $5.11 \pm 1.49^{\mathrm{a}}$ \\
\hline & \multicolumn{5}{|c|}{ Mix I } \\
\hline Water Activity & $0.98 \pm 0.00^{\mathrm{a}}$ & $0.98 \pm 0.00^{\mathrm{a}}$ & $0.98 \pm 0.00^{\mathrm{a}}$ & $0.98 \pm 0.00^{\mathrm{a}}$ & $0.98 \pm 0.00^{\mathrm{a}}$ \\
\hline Hardness (N) & $8.21 \pm 0.52^{\mathrm{bc}}$ & $17.69 \pm 3.22^{\mathrm{ab}}$ & $8.61 \pm 2.43^{\mathrm{bc}}$ & $5.86 \pm 1.65^{\mathrm{c}}$ & $20.76 \pm 3.00^{\mathrm{a}}$ \\
\hline Color L & $47.89 \pm 0.46^{\mathrm{a}}$ & $47.94 \pm 0.37^{\mathrm{a}}$ & $48.00 \pm 0.70^{\mathrm{a}}$ & $47.72 \pm 0.95^{\mathrm{a}}$ & $47.83 \pm 0.99^{\mathrm{a}}$ \\
\hline Color a & $5.24 \pm 0.77^{\mathrm{a}}$ & $5.88 \pm 0.64^{\mathrm{a}}$ & $5.64 \pm 0.64^{\mathrm{a}}$ & $5.22 \pm 1.05^{\mathrm{a}}$ & $5.52 \pm 1.26^{\mathrm{a}}$ \\
\hline Color b & $14.23 \pm 1.32^{\mathrm{a}}$ & $13.25 \pm 0.89^{\mathrm{a}}$ & $12.68 \pm 0.79^{\mathrm{a}}$ & $12.18 \pm 1.37^{\mathrm{a}}$ & $12.06 \pm 1.59^{\mathrm{a}}$ \\
\hline \multirow[t]{2}{*}{$\Delta \mathrm{E}$} & & $2.06 \pm 0.21^{\mathrm{a}}$ & $2.99 \pm 0.37^{\mathrm{a}}$ & $2.35 \pm 0.08^{\mathrm{a}}$ & $2.84 \pm 0.55^{\mathrm{a}}$ \\
\hline & \multicolumn{5}{|c|}{ Mix II } \\
\hline Water Activity & $0.98 \pm 0.01^{\mathrm{a}}$ & $0.98 \pm 0.00^{\mathrm{a}}$ & $0.98 \pm 0.00^{\mathrm{a}}$ & $0.98 \pm 0.00^{\mathrm{a}}$ & $0.98 \pm 0.00^{\mathrm{a}}$ \\
\hline Hardness (N) & $13.07 \pm 2.02^{\mathrm{a}}$ & $12.05 \pm 2.86^{\mathrm{a}}$ & $12.55 \pm 2.13^{\mathrm{a}}$ & $13.46 \pm 2.31^{\mathrm{a}}$ & $10.33 \pm 1.95^{\mathrm{a}}$ \\
\hline Color L & $39.05 \pm 0.34^{\mathrm{a}}$ & $36.41 \pm 0.11^{\mathrm{c}}$ & $37.05 \pm 0.27^{\mathrm{bc}}$ & $37.19 \pm 0.28^{\mathrm{bc}}$ & $38.04 \pm 0.29^{\mathrm{ab}}$ \\
\hline Color a & $5.56 \pm 0.88^{\mathrm{a}}$ & $4.91 \pm 0.59^{\mathrm{a}}$ & $6.63 \pm 1.02^{\mathrm{a}}$ & $6.84 \pm 0.87^{\mathrm{a}}$ & $9.08 \pm 0.69^{\mathrm{a}}$ \\
\hline Color b & $-5.07 \pm 0.50^{\mathrm{cb}}$ & $-0.38 \pm 0.22^{\mathrm{ab}}$ & $0.86 \pm 0.58^{\mathrm{ab}}$ & $1.05 \pm 0.60^{\mathrm{ab}}$ & $1.99 \pm 0.53^{\mathrm{a}}$ \\
\hline$\Delta \mathrm{E}$ & & $5.99 \pm 1.14^{\mathrm{a}}$ & $7.52 \pm 1.08^{\mathrm{a}}$ & $7.54 \pm 1.08^{\mathrm{a}}$ & $8.44 \pm 1.15^{\mathrm{a}}$ \\
\hline
\end{tabular}

Note. *Values of means \pm standard errors with same letter in a row are not significantly different at $p<0.05$.

\section{Conclusions}

Market demand for fermented vegetables, as with other fermented products, has increased due to their rich nutritional properties, better organoleptic characteristics, and for being safe products and a source of probiotics. These fermentation benefits make the fermented vegetables ideal candidates as alternative nutritional food sources both at home and, potentially, at commercial scale by the local food movement participants. The results from this study, show that the natural fermentation of vegetables can be completed in either 7 days or 10 days based on the observed physicochemical characteristics of vegetables. More research is needed to compare dry-salting methods. The use of a fermentation weight might be useful to prevent the growth of surface mold in dry-salted carrot, and it also may improve the surface color of dry-salted vegetables, because the weight forces the vegetables under the brine surface. Fermented vegetables, particularly produced through the dry-salting method, can be used as alternative fermented food products in the daily diet, especially because they can be produced easily at home.

\section{References}

Aizawa, K., \& Inakuma, T. (2007). Quantitation of Carotenoids in commonly consumed vegetables in Japan. 
Food Science and Technology Research, 13, 247-252. https://doi.org/10.3136/fstr.13.247

Altay, F., Karbancioglu-Guler, F., Daskaya-Dikmen, C., \& Heperkan, D. (2013). A review on traditional Turkish fermented non-alcoholic beverages: Microbiota, fermentation process and quality characteristics. International Journal of Food Microbiology, 167, 44-56. https://doi.org/10.1016/j.ijfoodmicro.2013.06.016

Anonymous. (2003). Precise color communication. Konica-Minolta. Retrieved April 25, 2017, from http://www2.konicaminolta.eu/eu/Measuring/pcc/en/part1/11.html

Association of Official Analytical Chemists. (2000). Official Method 962.12. In Official Methods of Analysis of AOAC International, $17^{\text {th }}$ Edition, 2, 70-75, AOAC, Gaithersburg, MD.

Arslan, S., \& Ozel, S. (2012). Some properties of stirred yoghurt made with processed grape seed powder, carrot juice or a mixture of grape seed powder and carrot juice. Milchwissenschaft-Milk Science International, 67(3), 281-285. Accession Number: WOS:000306160300014.

Cetin, B. Production of probiotic mixed pickles (Tursu) and microbiological properties. African Journal of Biotechnology, 10(66), 14926-14931. https://doi.org/10.5897/AJB11.2621

Cho, J., Lee, D., Yang, C., Jeon, J., Kim, J., \& Han, H. (2006). Microbial population dynamics of kimchi, a fermented cabbage product. FEMS Microbiology Letters, 257, 262-267. https://doi.org/10.1111/j.1574-6968.2006.00186.x

Damodharan, K., Palaniyandi, S. A., Yang, S. H., \& Suh, J. W. (2015). In vitro probiotic characterization of Lactobacillus strains from fermented radish and their anti-adherence activity against enteric pathogens. Canadian Journal of Microbiology, 61, 837-850. https://doi.org/10.1139/cjm-2015-0311\#.WQlWYlPyvq0

Daeschel, M. A., Anderson, R. E., \& Fleming, H. P. (1987). Microbial ecology of fermenting plant materials. FEMS Microbiology Letters, 46, 357-367. https://doi.org/10.1111/j.1574-6968.1987.tb02472.x

Deming, D. M., Boileau, A. C., Lee, C. M., \& Erdman, J. W. (2000). Amount of dietary fat and type of soluble fiber independently modulate postabsorptive conversion of beta-carotene to vitamin A in mongolian gerbils. Journal of Nutrition, 130, 2789-2796. PMID: 11053522, http://jn.nutrition.org/content/130/11/2789.long

Dunne, J. B., Chambers, K. J., Giombolini, K. J., \& Schlegel, S. A. (2010). What does 'local' mean in the grocery store? Multiplicity in food retailers' perspectives on sourcing and marketing local foods. Renewable Agriculture and Food Systems, 26(1), 46-59. https://doi.org/10.1017/S1742170510000402

Food and Agriculture Organization. (1998). Basic principles of fermentation (Chapter 2). Battcock, M., \& Azam-Ali, S. Fermented fruits and vegetables: A global perspective. Rome. Retrieved March 14, 2017, from http://www.fao.org/docrep/x0560e/x0560e07.htm

Feenstra, G. (2002). Creating space for sustainable food systems: Lessons from the field. Agriculture and Human Values, 19(2), 99-102._https://doi.org/10.1023/A:1016095421310

Goyeneche, R., Scala, K. D., \& Roura, S. (2013). Biochemical characterization and thermal inactivation of polyphenol oxidase from radish (Raphanus sativus var. sativus). Journal of Food Science and Technology, 54, 57-62. http://doi.org/10.1016/j.lwt.2013.04.014

Hunaefi, D., Akumo, D. N., \& Smetanska, I. (2013). Effect of fermentation on antioxidant properties of red cabbages. Food Biotechnology, 27, 66-85. https://doi.org/10.1080/08905436.2012.755694

Jagannath, A., Raju, P. S., \& Bawa, A. S. (2012). A two-step controlled lactic fermentation of cabbage for improved chemical and microbiological qualities. Journal of Food Quality, 35, 13-20. https://doi.org/10.1111/j.1745-4557.2011.00427.x

Jiang, J., Shi, B., Zhu, D. Q., Cai, Q. X., Chen, Y. R., Li, J. N., ... Zhang, M. (2012). Characterization of a novel bacteriocin produced by Lactobacillus sakei LSJ618 isolated from traditional Chinese fermented radish. Food Control, 23, 338-344. https://doi.org/10.1016/j.foodcont.2011.07.027

Johanningsmeier, S., Mcfeeters, R. F., Fleming, H. P., \& Thompson, R. L. (2007). Effects of Leuconostoc mesenteroides starter culture on fermentation of cabbage with reduced salt concentrations. Journal of Food Science, 72(5), 166-172. https://doi.org/10.1111/j.1750-3841.2007.00372.x

Joshi, V., K., \& Sharma, S. (2009). Lactic acid fermentation of radish for shelf-stability and pickling. Natural Product Radiance, 8(1), 19-24. URI: http://hdl.handle.net/123456789/3770, NPR 8(1) 19-24.pdf.

Joshi V. K., Sharma S., \& Thakur, N. S. (2008). Effect of temperature, salt concentration and fermentation type (inoculated vs natural) on lactic acid fermentation behavior and quality of carrot. Acta Alimentaria, 37(2), 
205-219. https://doi.org/10.1556/AAlim.37.2008.2.7

Kabak, B., \& Dobson, A. D. W. (2011). An Introduction to the traditional fermented foods and beverages of Turkey. Critical Reviews in Food Science and Nutrition, 51, 248-260. https://doi.org/10.1080/10408390903569640

Kalac, P., Spicka, J., Martin, K., \& Pelikanova, T. (2000). The effects of lactic acid bacteria inoculants on biogenic amines formation in sauerkraut. Food Chemistry, 70, 355-359. https://doi.org/10.1016/S0308-8146(00)00103-5

Karasu, N., Simsek, O., \& Con, A. H. (2010). Technological and probiotic characteristics of Lactobacillus plantarum strains isolated from traditionally produced fermented vegetables. Annals of Microbiology, 60, 227-234. https://doi.org/10.1007/s13213-010-0031-6

Lee, C. H. (1997). Lactic acid fermented foods and their benefits in Asia. Food Control, 8(5-6), 259-269. https://doi.org/10.1016/S0956-7135(97)00015-7

Martins, E. M. F., Ramos, A. M., Vanzela, E. S. L., Stringheta, P. C., Pinto, C. L. D., \& Martins, J. M. (2013). Products of vegetable origin: A new alternative for the consumption of probiotic bacteria. Food Research International, 51, 764-770. https://doi.org/10.1016/j.foodres.2013.01.047

Mizobutsi, G. P., Finger, F. L., Ribeiro, R. A., Puschmann, R., De Melo Neves, L. L., \& Da Mota, W. F. (2010). Effect of $\mathrm{pH}$ and temperature on peroxidase and polyphenoloxidase activities of litchi pericarp. Science and Agriculture, 67(2), 213-217. https://doi.org/10.1590/S0103-90162010000200013

Swain, N. R., Anandharaj, M., Ray, R. C., \& Rani, R. P. (2014). Fermented fruits and vegetables of Asia: A potential source of probiotics. Biotechnology Research International, 1-19. https://doi.org/10.1155/2014/250424

Thakur, P. K., \& Kabir, J. (2015). Effect of salt concentration on the quality of sauerkraut. Journal Crop and Weed, 11(1), 46-48.

Viander, B., Maki, M., \& Palva, A. (2003). Impact of low salt concentration, salt, quality on natural large-scale sauerkraut fermentation. Food Microbiology, 20, 391-395. https://doi.org/10.1016/S0740-0020(02)00150-8

\section{Copyrights}

Copyright for this article is retained by the author(s), with first publication rights granted to the journal.

This is an open-access article distributed under the terms and conditions of the Creative Commons Attribution license (http://creativecommons.org/licenses/by/4.0/). 